This item was submitted to Loughborough's Research Repository by the author.

Items in Figshare are protected by copyright, with all rights reserved, unless otherwise indicated.

\title{
Pressure electroosmotic dewatering with continuous removal of electrolysis
} products

PLEASE CITE THE PUBLISHED VERSION

PUBLISHER

(c) Elsevier

VERSION

AM (Accepted Manuscript)

LICENCE

CC BY-NC-ND 4.0

\section{REPOSITORY RECORD}

Larue, O., Richard J. Wakeman, E.S. Tarleton, and E. Vorobiev. 2009. "Pressure Electroosmotic Dewatering with Continuous Removal of Electrolysis Products". figshare. https://hdl.handle.net/2134/4770. 
This item was submitted to Loughborough's Institutional Repository (https://dspace.lboro.ac.uk/) by the author and is made available under the following Creative Commons Licence conditions.

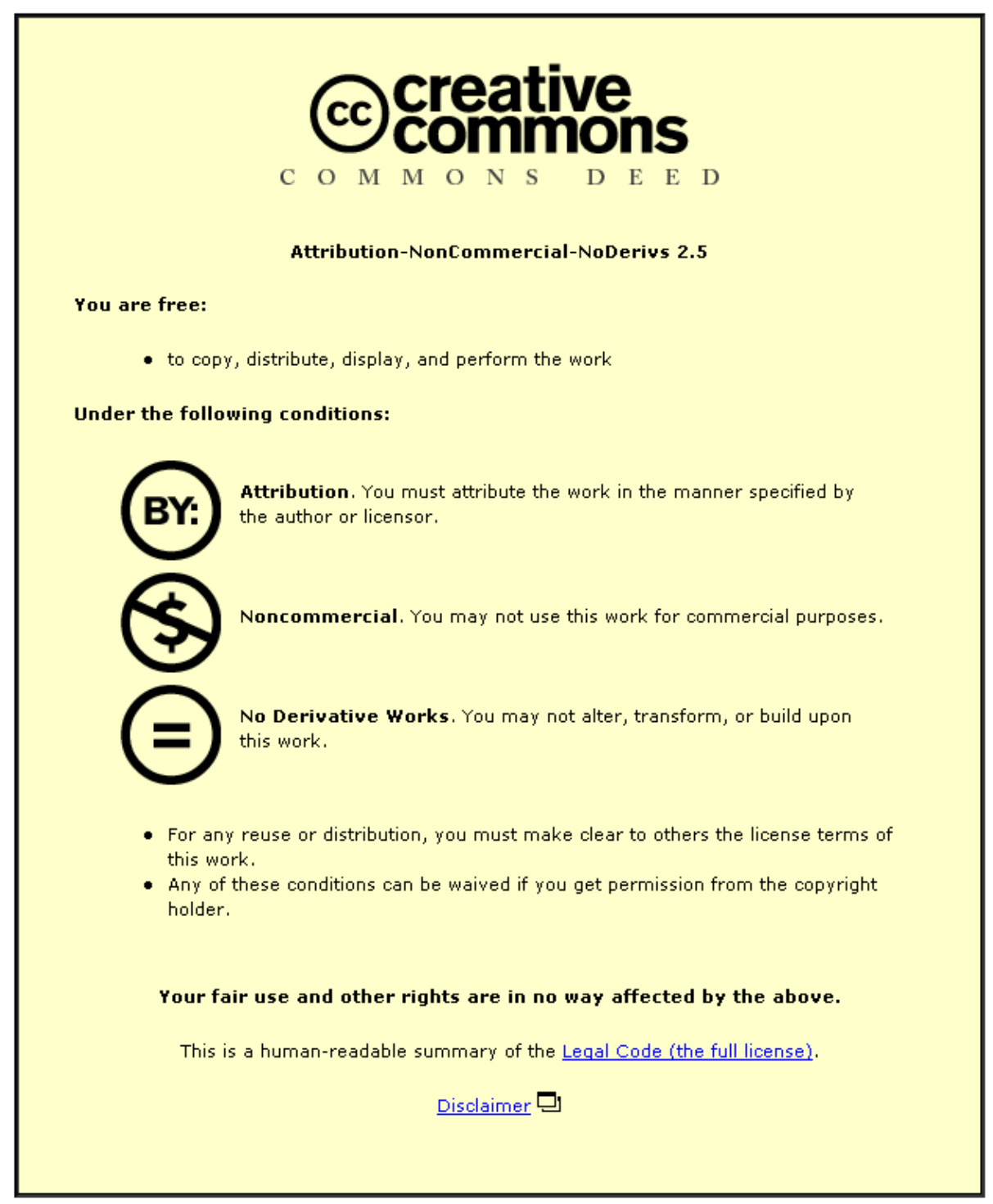

For the full text of this licence, please go to: http://creativecommons.org/licenses/by-nc-nd/2.5/ 


\title{
PRESSURE ELECTROOSMOTIC DEWATERING WITH CONTINUOUS REMOVAL OF ELECTROLYSIS PRODUCTS
}

\author{
O. Larue ${ }^{a}$, R.J. Wakeman ${ }^{b}$, E.S. Tarleton ${ }^{b}$ (e.s.tarleton@lboro.ac.uk) and E.Vorobiev ${ }^{a}$ \\ ${ }^{\mathrm{a} C}$ Chemical Engineering Department, University of Compiègne, Compiègne, BP 20529-60205, \\ France. \\ ${ }^{\mathrm{b}}$ Advanced Separation Technologies Group, Department of Chemical Engineering, Loughborough \\ University, Loughborough, Leics., LE11 3TU, UK.
}

\begin{abstract}
Pressurised electroosmotic dewatering (PED) is usually implemented in classical filters with the electrodes making a direct contact with the material or the filter cloths. Thus, electrolysis products generated at the electrodes (gas, ions) tend to accumulate in the solid/liquid mixture being dewatered. This results in a non-uniform distribution of water content, porosity, electric field intensity, and particle zeta potential throughout the mixture, affecting progress of the PED process. This paper proposes a specific design of filter press to study PED in the absence of disturbances from electrolysis products. An experimental study was carried out on a gelatinous bentonite suspension at $8.5 \% \mathrm{w} / \mathrm{w}$ solid. The influence of the ionic conductivity of suspension $(2-25 \mathrm{mS} / \mathrm{cm})$, the current intensity (20-300 mA) and the pressure (2.5-15 bar) were investigated. In order to improve the energetic yield of PED, the conductivity and current intensity should be limited, as observed in earlier works. The pressure increase considerably aids the water removal and leads to better product dryness. For PED at 15 bar and $100 \mathrm{~mA}$, the bentonite reached $40 \% \mathrm{w} / \mathrm{w}$ solid for $0.7 \mathrm{kWh} / \mathrm{kg}$ of water removed. This study emphasizes that to analyse PED precisely it is important to clarify the dependence of the electroosmotic flow rate on the porosity and pressure.
\end{abstract}

\section{KEYWORDS}

Filtration; Suspension; Bentonite; Electric field; Electroosmosis; Electrolysis

\section{INTRODUCTION}

Dewatering techniques based on a single non-thermal driving force (pressure, vacuum, centrifugal force) are inefficient for colloidal or gelatinous suspensions, leading to the formation of low permeability cakes. Classical physical and chemical methods such as high pressure or flocculant addition enhance the mechanical dewatering. However, their use in industry can be limited by subsequent processing requirements or use of the filtration products. Specific expensive equipment is required to process at high pressures. Flocculants reduce product dryness and may alter the final product quality. These drawbacks have led many researchers to exploit interfacial electrokinetic properties of particles in suspension. Emergent technologies have been implemented based on the application of an external electric field (Moulik, 1971) complemented or not by acoustic fields (Tarleton, 1990; Wakeman and Tarleton, 1991). The processes investigated utilising an electric field include electrosedimentation to enhance sedimentation (Shirato et al., 1979); electrofiltration to enhance filtration or to reduce membrane fouling in crossflow filtration (Yukawa et al., 1976; Visvanathan and Ben Aïm, 1989; Wakeman and Sabri, 1995; Akay and Wakeman, 1997; Wakeman, 1998; Weber and Stahl, 2002a), and more recently electrowashing to remove specific solutes in porous media (Ghirisan et al., 2002; Tarleton et al., 2003). However, most research has concentrated on pressurised electroosmotic dewatering (PED), that is, the application of a DC electric field during the expression of formed cakes or porous media (Sprute and Kelsh, 1980; Lockhart, 1983; Iwata et al., 1991; Barton et al., 1999; Weber and Stahl, 2002b). Macroscopic modelling efforts have been attempted to analyse PED behaviour in saturated water media. Yukawa et al. (1971) have shown that the electric field aids pressure driven removal of the 
interstitial liquid by creation of an additional electroosmotic flow. They developed an equation to describe the kinetics of liquid removal in PED of a saturated porous material as:

$$
q=q_{p}+q_{E}=-\frac{1}{\mu \alpha \rho_{s}(1-\varepsilon)} \frac{\partial P_{L}}{\partial z}-\frac{D \varphi(\varepsilon) \zeta}{k \mu} \frac{\partial \psi}{\partial z}
$$

where $q$ is the superficial liquid velocity, $\alpha$ is the specific cake resistance, $\rho_{S}$ is the density of solid particles, $\mu$ is the liquid viscosity, $z$ is a co-ordinate, $P_{L}$ is the liquid pressure in cake pores, $k$ is a particle shape factor, $D$ is the dielectric constant of the interstitial liquid, $\zeta$ is the particle zeta potential and $\psi$ is the electric potential. $\varphi(\varepsilon)$ is a function of the cake porosity $\varepsilon$ dependent on the material being dewatered. Yukawa et al. (1971) found experimentally that $\varphi(\varepsilon)$ is nearly equal to $\varepsilon$ within a certain region of $\varepsilon$ for silica and calcite. In equation (1), $q_{P}$ displays the Darcy law proportionality between the liquid velocity and the pressure gradient. The term $q_{E}$ defines the electroosmotic contribution which is proportional to the gradient of electrical potential (that is, the electric field intensity $E=\partial \psi / \partial z$ ). Maclnnes et al. (2003) have shown that slip flow in microchannels is proportional in the exact parametric dependence shown in equation (1) outside a Debye scale double layer. Therefore, for a given porosity, equation (1) holds in a steady flow. During the expression of formed cakes or porous media, as porosity $\varepsilon$ decreases and the specific cake resistance $\alpha$ increases, the superficial liquid velocity $q$ declines along PED in accordance with equation (1). The compaction front can be modelled based on equation (1) using the mass balance $(\partial e / \partial t)=(\partial q / \partial w)$ with (e: void ratio, $t$ : time; $\partial w$ : element volume of the material) (Iwata et al., 1991; Zimmerman and Routh, 2004). It was shown that PED may be considered equivalent to a consolidation process since it accompanies the increase of solid compressive pressure.

The typical increase of cake dryness is around $10-15 \% \mathrm{w} / \mathrm{w}$ for a large range of colloidal materials compared to mechanical dewatering alone (Sprute and Kelsh, 1980; Lockhart, 1986; Ju et al., 1991; Barton et al., 1999). Though this gain is significant, the authors reported that PED performance suffered due to property changes caused by electrical contacts at the electrode (with the product or the filter cloth and product) leading to termination of the operation of the process. They noted a non-uniform distribution of water content, $\mathrm{pH}$, porosity, electric field intensity and particles zeta potential throughout the mixture. The electrolysis reactions at the electrodes account for this behaviour (Larue and Vorobiev, 2004).

This paper presents an experimental study of PED using a filter press design able to remove the electrolysis products generated at the electrodes. A stainless steel-stainless steel couple of electrodes were chosen for this work. The electrodes were placed downstream of the filter cloths/cake without direct contact with the cloth or cake, in a flowing electrolyte solution that ensures the current to flow between the electrodes and the product (Hofmann and Posten, 2003). In addition, the solution swept away continuously the electrolysis products and the filtrate, and transferred the heat out of the filter chamber. Such an arrangement was planned to yield throughout PED a more uniform dewatering, a constant $\mathrm{pH}$, and a constant viscosity and zeta potential throughout the material being dewatered. The progression of PED was observed while expressing a gelatinous bentonite suspension under constant pressure and DC electric field. The influences of some of the parameters in equation (1) were investigated in this paper: the pressure, the electric field intensity (by a current intensity change) and the particle zeta potential (by an electrical conductivity change). The evolution of the parameter $\varphi(\varepsilon)$ was also discussed.

\section{BACKGROUND}

For optimising the electricity consumption in PED, control of the parameters influencing $\psi$ must be achieved. The overall potential $\psi$ can be divided into several terms (Vijh, 1999):

$$
\psi=\psi_{0}+\psi_{s}+\psi_{\Omega}
$$


where $\psi_{0}$ corresponds to the difference between the electrochemical potentials theoretically needed for the electrolysis reactions to occur; $\psi_{s}$ is the product-electrode overpotential having quite complex contributions (electron transfer, kinetics of ion adsorption at the electrode surface, mass transfer by diffusion, etc.). The electrode material must be chosen empirically to minimise the overpotential and energy consumption in PED (Lockhart, 1983c; Vorobiev and Jany, 1999). The factor $\psi_{\Omega}$ is the ohmic potential caused by the product electrical resistance dependent on its thickness, dryness and ionic concentration.

Equation (1) also revealed that the PED kinetics evolve in relation with the structural properties of the product $(\varepsilon, \alpha)$ and the electrical parameter $\zeta$ of the particles. The $\zeta$ potential is influenced by the nature of the particles in the product, and the type and concentration of ions in the interstitial liquid. The electroosmotic flow rate is improved in stable colloidal systems (particles $<5 \mu \mathrm{m}$ ) owing to a higher $|\zeta|$ value. It is also improved in compressible gelatinous suspensions not easily treated by mechanical compression, exhibiting a dryness after compression $<20 \% \mathrm{w} / \mathrm{w}$ solids (Yoshida et al., 1985; Ju et al., 1991). Lockhart (1983b), working on clays (montmorillonite and kaolinite), proved that the ionic charge in the liquid in a porous medium has a significant effect. Electroosmosis performed better in presence of cations $\left(\cong 10^{-2} \mathrm{~mol} / \mathrm{L}\right)$ than in deionised water. The electroosmosis mechanism accounts for this phenomenon. As regards the double layer theory (Overbeek and Bijsterbosch, 1979), ions organise around the particle in two layers to compensate its electrical surface charge (usually negative): an inner layer where ions are chemically bound to the particle and at outer layer where ions are electrostatically attracted by the particle surface charge. When an external electric field is applied, the outer part is removed with surrounding water (electroosmosis). Thus, electrolytes must be available in the liquid to maintain the electroosmotic effect. However, the ionic concentration should not be too high otherwise compression of the electrical double layer causes $|\zeta|$ to decrease. The nature of the ions dispersed in the salt solution or electrolysis reactions at electrodes can be influential; for example, strong electropositive cations $\left(\mathrm{Al}^{3+}, \mathrm{Ca}^{2+}, \mathrm{Fe}^{3+}\right)$ or specific ions $\left(\mathrm{OH}^{-}, \mathrm{H}_{3} \mathrm{O}^{+}\right)$may interact with particles in the product affecting $|\zeta|$ and the electroosmotic flow rate (Wakeman, 1982; Lockhart, 1983b). A number of researchers have addressed for optimisation of PED by adjusting the parameters described earlier. These works usually use a typical filter press enhanced by electrodes making direct contact with the filter cake or the filter cloth (Sprute and Kelsh, 1980; Lockhart, 1986; Ju et al., 1991; Barton et al., 1999). But in such an arrangement the electrolysis reactions at electrodes are likely to stop the PED process.

\section{Electrolysis Reactions at Electrodes}

Lockhart (1983c) has described the main possible electrolysis reactions at the electrodes in aqueous media as follows:

Anode:

$M_{(\mathrm{s})} \rightarrow M^{n+}(\mathrm{aq})+n \mathrm{e}^{-}$

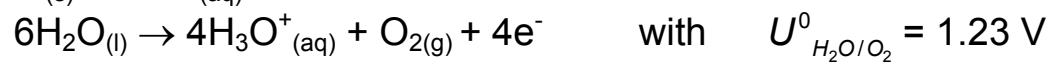

\section{Cathode:}

$$
\begin{aligned}
& 2 \mathrm{H}_{2} \mathrm{O}_{(\mathrm{l})}+2 \mathrm{e}^{-} \rightarrow 2 \mathrm{OH}_{(\mathrm{aq})}^{-}+\mathrm{H}_{2(\mathrm{~g})} \quad \text { with } \quad U_{\mathrm{H}_{2} / \mathrm{H}_{2} \mathrm{O}}^{0}=-0.83 \mathrm{~V} \\
& 2 \mathrm{H}_{3} \mathrm{O}^{+}{ }_{(\mathrm{aq})}+2 \mathrm{e}^{-} \rightarrow 2 \mathrm{H}_{2} \mathrm{O}_{(\mathrm{l})}+\mathrm{H}_{2(\mathrm{~g})} \quad \text { with } \quad U_{\mathrm{H}_{2} / \mathrm{H}_{3} \mathrm{O}^{+}}^{0}=0 \mathrm{~V}
\end{aligned}
$$

$M$ is the material used in anode; $U_{\mathrm{H}_{2} \mathrm{O} / \mathrm{O}_{2}}^{0}$ is the standard potential at the electrode at $298 \mathrm{~K}$ required to make possible the reaction $(\mathrm{A} 2)$ in the absence of kinetics restrictions. For instance, the reaction (A1) is dominant for an oxidisable metal generating metal ions. Electrolytic ions $M^{\text {n+ }}$ provide charges in the liquid that may be beneficial to maintain the electroosmotic process. $\mathrm{But} \mathrm{pH}$ 
conditions may transform metal ions into insoluble hydroxide species $\left(\mathrm{M}^{\mathrm{n}+}+\mathrm{OH}^{-} \rightarrow M(\mathrm{OH})_{n}\right)$ that are likely to plug the filter cloth or deteriorate the product quality (Larue et al., 2001). Then, the reaction (A2) must be dominant if the product does not tolerate any electrolytic chemicals. This is achieved with non-oxidisable electrodes (graphite, titanium or conductive ceramics). However, it was observed that PED deterioration inevitably occurs. The rapid decrease of water content in the material starts from a region near the electrode where flow is opposite to electroosmotic drainage due to ohmic heating and electrolytic gas formation (as shown in equations C1 and C2). The electrical resistance at the contact electrode-filter cake (or electrode-filter cloth-filter cake) then rises remarkably, thus $\psi \rightarrow 0$ and the electroosmotic flow stops (Yoshida et al., 1999). Note that electrolytic ions $\mathrm{H}_{3} \mathrm{O}^{+}$and $\mathrm{OH}^{-}$may also have a negative effect on the electroosmotic flow (equations $\mathrm{A} 2$ and $\mathrm{C} 1$ ), especially in clays. For instance, if a DC electric field is applied, $\mathrm{H}_{3} \mathrm{O}^{+}$ions accumulate in the filter cake with the anode side becoming acid and $\mathrm{OH}^{-}$ions at the cathode side becoming basic (Larue and Vorobiev, 2004). In acidic conditions, the adsorption $\mathrm{H}_{3} \mathrm{O}^{+}$on usually negatively charged particles (clays) make $|\zeta|$ collapse, thus the electroosmotic drainage will cease in the cake at the anode side. In order to enhance PED, the effects of electrochemical reactions inducing high local resistances should be reduced. Then, instead of a classical full time DC electric field, Lockhart and Hart (1988) and Gopalakrishnan et al. (1996) proposed a DC electric field interrupted by short periodic reversal of electrode polarity. They noticed the polarity reversal promotes a more uniform $\mathrm{pH}$, water content and thus electroosmotic dewatering through the filter cake (and at the same time 20 to $40 \%$ more water was extracted).

\section{EXPERIMENTAL}

\section{Description of the Filter Arrangement}

The automated apparatus shown in Figure 1 was designed in the Department of Chemical Engineering of Loughborough University. It facilitated simultaneous upward and downward constant pressure filtration. The arrangement comprised means for delivering compressed air in a load device. A PC was used to control the rate of compressed air in order to maintain a constant load (up to $325 \mathrm{~kg}$ ). The load was transmitted to the filter cell made up of three cylindrical parts in polypropylene: a piston $(\varnothing 5.1 \mathrm{~cm}$ ), a filter chamber (internal $\varnothing 5.2 \mathrm{~cm}$, external $\varnothing 10 \mathrm{~cm}$ ), and a filter base (external $\varnothing 13.6 \mathrm{~cm}$ ). The filter base includes in its centre a cylindrical cavity of $1 \mathrm{~cm}$ depth with the same internal diameter as the filter chamber $(\varnothing 5.2 \mathrm{~cm})$. The cavity is covered by a polypropylene filter cloth $(\varnothing 10 \mathrm{~cm}$; aperture size $2 \mu \mathrm{m})$. A stainless steel electrode was inserted on the cavity bottom. A polypropylene insert $(1 \mathrm{~cm}$ height) in the cavity serves to support the filter cloth once the pressure is applied as well as acting as a vessel for the conductive solution that removes electrolysis products from the electrode. The insert was designed to allow easy flow for the solution and to prevent formation of a non-conductive gas layer in the cavity. An identical arrangement (that is, cavity of $1 \mathrm{~cm}$ height, polypropylene insert, stainless steel electrode) was designed inside the piston head. Wires were used to link electrodes to a DC power supply SM12013 (Delta Elektronica, The Netherlands) operating in a constant current mode up to $13 \mathrm{~A}$. In PED tests, the cavities in the piston and filter base were preliminary filled with the conductive solution. A recirculation of this solution from the filter to a $2 \mathrm{~L}$ collecting vessel was ensured via pipework and peristaltic pumps 502S, $503 \mathrm{~S}$ (Watson-Marlow, UK). The conductive solution, prepared with 1 $L$ of deionised water, sodium sulphate salt and sodium hydroxide (assay $>99 \%$, Fisher Chemicals), had the same $\mathrm{pH}$ and conductivity as the bentonite suspension. Active carbon (grade DCL200, Sutcliffe Speakman Carbons Ltd, UK) was also added at $2 \mathrm{~g} / \mathrm{L}$ to this solution to remove continuously the electrolysis ions formed during PED.

\section{Description of the Bentonite Suspension}

The bentonite has a density of $2.6 \mathrm{~g} / \mathrm{cm}^{3}$, and was supplied as dry powder (A.P.I Wyoming, USA) and predominantly, but not exclusively, composed of sodium montmorillonite. Montmorillonite is a 
di-octahedral smectite mineral exhibiting a layered crystal structure with negative surface electrical charges. The clay swells in water by taking up inter-layer water. The average particle size measured by MastersizerX (Malvern, UK) is $5 \mu \mathrm{m}$. Identical bentonite suspensions were prepared for each experiment. First, $200 \mathrm{~g}$ of deionised water were added to known quantities of sodium sulphate. Subsequently, this solution was made up with $20 \mathrm{~g}$ of bentonite powder and agitated rapidly for five minutes $(200 \mathrm{rpm})$. This yielded a gelatinous bentonite suspension at $8.5 \% \mathrm{w} / \mathrm{w}, \mathrm{pH}$ 9 and at the desired conductivity. This suspension was subsequently homogenised for one hour at $100 \mathrm{rpm}$.

\section{Filtration}

Ninety five millilitres of bentonite suspension was poured into the filter chamber (height of bentonite suspension: $45 \mathrm{~mm}$ ). Filtration in the range 2.5-15 bar was started using the computer to maintain a constant pressure. Parameters recorded are the constant load (automatically) and the piston position $H$ in millimetres (using a digital reader). The volume of filtrate $V$ was derived from calculation from the piston course ( $V=A \times H ; A$ : filter surface). Since the bentonite cake is highly compressible, extended filtration times were required at any pressures. Bentonite cakes displayed high specific resistances: $3.5 \times 10^{15} \mathrm{~m} / \mathrm{kg}$ at 5 bar, $1.5 \times 10^{16} \mathrm{~m} / \mathrm{kg}$ at 10 bar. Bentonite cakes had a high porosity $(\varepsilon=0.92$ for $20 \% \mathrm{w} / \mathrm{w}$ solid).

\section{PED Test}

The upward and downward filtration led to the formation of two densified regions of suspension (which or may not have formed a cake in the strict sense), with unfiltered suspension remaining between the upward and downward growing regions. At a given filtration time (5000 or $20000 \mathrm{~s}$ ), a constant current intensity was applied in the range 20-300 mA to accelerate the cake formation and consolidation. The densified regions or cakes became indistinguishable from the suspension at a solids concentration of $20 \%$. The constant current was maintained until the water extraction by PED became negligible. The parameters recorded were: the voltage and current, and the $\mathrm{pH}$ and solution temperature in the vessel using a pH meter Hydrus 500 (Fisherbrand). The temperature in the filter cake was measured by a digital reader KM3002 (Kane-May Measuring Instruments) connected to a thermocouple inserted between the filter chamber and the filter cloth. In order to control the filter cake temperature, the collecting vessel was placed in a water reservoir cooled by a SK428 TC 476 Tecam bath cooler. At the experiment end, the filter cake was discharged to determine its thickness, dryness (after $24 \mathrm{~h}$ in oven at $105^{\circ} \mathrm{C}$ ) and porosity. The average dryness of bentonite as well as the average cake porosity were calculated at any process time knowing the piston position, the final cake dryness and porosity. The water volume electrically removed, $V_{E}(t)$, was estimated from the overall filtrate volume $V(t)$ since $V_{E}(t)=V(t)$ $V_{P}(t)$ where $V_{P}$ is the volume extracted mechanically which was determined experimentally from an ordinary filtration test. For some experiments, the specific energy consumption in $\mathrm{kWh} / \mathrm{kg}$ of water removed by electroosmosis was derived from the values of $V_{E}(t)$ and the electrical parameters (current and voltage).

\section{RESULTS AND DISCUSSION}

\section{Preliminary Observations}

The conductive solution removed efficiently the electrolytic gas bubbles formed at the electrodes during PED. The solution, circulating between the filter and the pipes network is degassed in the 2 $\mathrm{L}$ collecting vessel (Figure 1). The active carbon added to the solution removed the metal ions to reduce contamination of the cake; deposits of metal ions were actually absent from filter cake and filter cloths in all PED tests. Two tests were carried out with a bentonite suspension at $6 \mathrm{mS} / \mathrm{cm}$, with and without use of the cooling system shown in Figure 1. Both tests started with $5000 \mathrm{~s}$ of ordinary filtration at 10 bar, to which was subsequently added a constant $100 \mathrm{~mA}$ current. Figure 2 
presents the temperature evolution in the conductive solution and in the filter cake during current application. Figure 2 shows that the cooling system is able to adjust the filter cake temperature to $20^{\circ} \mathrm{C}$. In the absence of cooling, the temperature elevation in filter cake was $16.5^{\circ} \mathrm{C}$ after $20,000 \mathrm{~s}$ of PED. The temperature increase reduces the viscosity $\mu$ in the interstitial liquid in the cake pores, which should yield a better mechanical extraction according to equation (1). If all other parameters were unchanged this change in temperature would be expected to cause a $47 \%$ increase of the fluid flux due to the viscosity reduction alone, but the electroosmotic flow rate, the final product dryness and the specific energy consumption were actually almost identical. Nevertheless, the further experiments were conducted with the cooler in order to adjust the cake temperature at $20 \pm 2^{\circ} \mathrm{C}$ and then to fix the variable $\mu$ in order to improve the analysis of PED results.

\section{Effect of Ionic Concentration}

A series of experiments was carried out to check the effect of bentonite conductivity. It was varied from 2 to $25 \mathrm{mS} / \mathrm{cm}$, by adding $1.4 \times 10^{-2}$ to $1.8 \times 10^{-1} \mathrm{~mol} \mathrm{~L}^{-1}$ of sodium sulphate to the bentonite suspension. After $20,000 \mathrm{~s}$ of ordinary filtration at 10 bar, where the filtrate collected was $32( \pm 2.5)$ $\mathrm{mL}$, a current of $100 \mathrm{~mA}$ was applied. The bentonite only gained $2 \% \mathrm{w} / \mathrm{w}$ dryness for $20,000 \mathrm{~s}$ of filtration (from 8.5 to $10.5 \%$ ). Afterwards, with the electrical current it increased from $10.5 \%$ to $35 \% \mathrm{w} / \mathrm{w}$ in the much shorter time of $15,300 \mathrm{~s}($ at $6 \mathrm{mS} / \mathrm{cm}$ ). The final cake thickness was $0.8 \mathrm{~cm}$ and $75 \%$ of water was removed by PED for the bentonite at $6 \mathrm{mS} / \mathrm{cm}$. Figure 3 shows the filtrate volume removed in PED and in ordinary filtration without an electric field (taken as a reference) as a function of time. The volume of water extracted by PED falls for high ionic concentration towards that obtained with ordinary filtration. This result is in agreement with equation (1): a higher conductivity leads to a lower electric field intensity and electroosmotic flow rate. The particle zeta potential was assessed for the different conductivities. Table 1 presents the electroosmotic flow rate in PED for $20 \% \mathrm{w} / \mathrm{w}$ of cake solids, the electric field intensity $E$ and the particles zeta potential calculated as $\zeta=-k \mu q_{E} / D E \varphi(\varepsilon)$. For $20 \% \mathrm{w} / \mathrm{w}$ of solids, $\varphi(\varepsilon)$ is close to $\varepsilon=0.92$, the particles shape factor was assumed to be $k=10$ for the flaky bentonite particles (Yu et al., 1996). The dielectric constant of water is $D=6.94 \times 10^{-10} \mathrm{~F} / \mathrm{m}$. The such calculated zeta potential is in good agreement with zeta potential $\zeta=-14 \mathrm{mV}$ measured by Ju et al. (1991) for a bentonite suspension at $9.1 \% \mathrm{w} / \mathrm{w}$ with $10^{-2} \mathrm{~mol} \mathrm{~L}{ }^{-1}$ of $\mathrm{CaCl}_{2}$. Table 1 shows the zeta potential is actually steady at around $-16 \mathrm{mV}$ between 2 and $10 \mathrm{mS} / \mathrm{cm}$, but it rises to $-7.8 \mathrm{mV}$ at $25 \mathrm{mS} / \mathrm{cm}$. This accounts for the results presented in Figure 4 displaying the specific energy consumption as a function of cake dryness. From 2 to $10 \mathrm{mS} / \mathrm{cm}$, the curves of specific energy consumption are almost coincident. Thus, the electric power required to extract the same quantity of water is almost the same from 2 to $10 \mathrm{mS} / \mathrm{cm}$. However, the electric power for dewatering the cake is much higher at $25 \mathrm{mS} / \mathrm{cm}$ owing to the zeta potential increase.

\section{Monitoring the PED Process}

Three PED experiments were repeated on bentonite suspensions at $6 \mathrm{mS} / \mathrm{cm}$ using the same procedure $(20,000 \mathrm{~s}$ of ordinary filtration at 10 bar subsequently combined to $100 \mathrm{~mA})$. Figure 5 shows the average electroosmotic flow rate $q_{E}$, derived from the slope of $V_{E}(t) v s$. $t$ curves. Figure 6 presents the average specific energy consumption and the electric field intensity $E$ (voltage divided by electrodes spacing) as functions of the average bentonite dryness. Uncertainties observed in the specific energy consumption were essentially caused by the variations in electroosmotic flow rate from one experiment to another (error bars in Figures 5 and 6). Even slight alterations in the history of the cake formation during filtration might explain variations in cake tortuosity and thus in electroosmotic flow (and in specific energy consumption).

Figure 5 shows that the electroosmotic flow first progressed from nearly nil to a maximum value at around $12 \% \mathrm{w} / \mathrm{w}$ of bentonite dryness in $2000 \mathrm{~s}$. This progression may be explained by the microscopic nature of the electroosmotic phenomenon taking place around each particle. Since the filter cake has a tortuous structure, a certain time is required to yield a maximum 
electroosmotic dewatering at the cake outlet from all the particles contributions inside the cake. A constant and maximum electroosmotic flow rate is observed between $12 \%$ and $20 \% \mathrm{w} / \mathrm{w}$ of dryness $\left(q_{E}=2.2 \pm 0.2 \times 10^{-6} \mathrm{~m} / \mathrm{s}\right)$, with a corresponding minimal specific energy consumption $(0.45 \pm 0.5 \mathrm{kWh} / \mathrm{kg}$ of water removed). In this range of bentonite dryness, PED is electrofiltrationlike since unfiltered suspension still remained between the upward and downward growing cake portions. Once both the cake parts had become indiscernible from the rest of the suspension at $20 \%$ cake dryness $(\varepsilon=0.92)$ consolidation took place. The electroosmotic flow rate regularly declined owing to the reduction in cake porosity. There was consequently an increase in specific energy consumption until $0.65 \mathrm{kWh} / \mathrm{kg}$ (at $35 \mathrm{wt} \%, \varepsilon=0.82$ ) after $15,300 \mathrm{~s}$ of PED. Figure 6 shows that $E$ slightly increased during PED since the electrodes get closer (as the piston moved downwards) and since the dewatered material gained a higher electrical resistance. The average voltage was $60 \mathrm{~V}$ at the start of PED and $80 \mathrm{~V}$ after 15,300 s, when the current was turned off.

\section{Effect of Current Intensity}

Equation (1) indicates that an increase in electric field intensity $E$ (thus in current intensity) is related to an increase in PED kinetics. Figure 7 shows the filtrate volume recovered in PED (after $5000 \mathrm{~s}$ of filtration at $10 \mathrm{bar}$ ) as a function of time. With the current intensity varying from 20 to 300 $\mathrm{mA}$, the slope of curves filtrate volume vs. time rises, showing an increase of PED kinetics. Also, higher current intensity improved the water removal and product dryness. Nevertheless, the current or electric field intensity should be limited to avoid high energy consumption by ohmic losses. Figure 8 presents the specific energy consumption for the tests of Figure 7 . Ohmic losses have a strong impact at higher current intensities. It is quite useless to provide high electric field intensity to reduce the process time since ohmic losses will play an important role in reducing the energetic yield from the process. An optimum point has to be found for the process time and the electric power applied (Larue et al., 2001).

\section{Effect of Pressure}

A series of experiments was carried out to study the effect of pressure in PED. Initially, $5000 \mathrm{~s}$ filtrations were performed at fixed pressures from 2.5 to 15 bar, and these were subsequently combined with experiments in which $100 \mathrm{~mA}$ was added. Figure 9 shows the specific energy consumption in PED at constant pressures from 2.5 to 15 bar. As the bentonite is a compressible material, the increase in pressure in ordinary filtration did not improve the filtration kinetics. The cakes dryness at filtration end was around $10.5 \% \mathrm{w} / \mathrm{w}$ at any pressures tested. In PED, the electroosmotic flow rate was almost identical from 10.5 to $20 \mathrm{wt} \%$ at 2.5 to 15 bar, as was the specific energy consumption as shown in Figure 9. In this region of cake dryness, the process was 'electrofiltration-like'. After $20 \% \mathrm{w} / \mathrm{w}$ of bentonite dryness, the filter cake entered into consolidation. At this point there was a large improvement in electroosmotic flow rate with the increase of pressure. As a result, the specific energy consumption was reduced at higher pressures and the bentonite dryness reached for an identical energy input was improved, as shown in Figure 9. The bentonite dryness reached $40 \% \mathrm{w} / \mathrm{w}$ with PED at 15 bar for $0.7 \mathrm{kWh} / \mathrm{kg}$ of water removed. The consolidation stage after $20 \% \mathrm{w} / \mathrm{w}$ allows the use of equation (1). Indeed, with the specific filter design the cake porosity $\varepsilon$, the specific cake resistance $\alpha$, the electric field intensity $E$, the zeta potential $\zeta$ may be assumed as homogeneous throughout the filter cake in the consolidation stage. It seems interesting to focus on a parameter of equation (1) the function of the porosity $\varphi(\varepsilon)$. Yukawa et al. (1971), working on PED of silica and calcite, have shown that $\varphi(\varepsilon)$ is nearly equal to $\varepsilon$ within a certain region of $\varepsilon$. In this study, the evolution of this parameter was noted to depend not only on the porosity but also on the pressure applied. Based on $q_{E}$ values shown in Figure 5 , on $E$ values shown in Figure 6 , the function of porosity $\varphi(\varepsilon)$ was calculated from equation $(1)$ as $\varphi(\varepsilon)=$ $D E \zeta / k \mu q_{E}$ (with $k=10$ and $\mu=10^{-3} \mathrm{~Pa} \mathrm{~s}$ ). The $\zeta$ potential was supposed to remain constant in PED $(\zeta \sim-16 \mathrm{mV}$ for bentonite at $6 \mathrm{mS} / \mathrm{cm})$. Figure 10 shows the $\varphi(\varepsilon)$ evolution with the cake porosity for these tests. At any pressure, $\varphi(\varepsilon)$ decreases with the reduction of porosity throughout PED. For $20 \% \mathrm{w} / \mathrm{w}$ cake dryness $(\varepsilon=0.93)$, at any pressure $\varphi(\varepsilon)$ is close to 1.2 . However, Figure 10 shows that the decrease of $\varphi(\varepsilon)$ with the reduction of porosity depends clearly on the pressure 
applied. In order to analyse PED precisely, it is important to make clear the dependence of $\varphi(\varepsilon)$ with the porosity and pressure.

\section{CONCLUSION}

In this experimental study a bentonite suspension at $8.5 \% \mathrm{w} / \mathrm{w}$ solid was dewatered by pressurised electroosmosis with continuous removal of the electrolysis products produced at the electrodes. The main results are summarised as follows:

1. Oxidisable electrodes yielding low overpotential can be used without any cake contamination by the side-products of electrolysis.

2. The cooled solution used to remove electrolysis products at the electrodes also dissipates heat out of filter chamber. The filter cake temperature can then be controlled to constant value.

3. Higher conductivity of bentonite tends to decrease the PED kinetics due to the modulus of the zeta potential decreasing.

4. Higher current intensity improves the PED kinetics and yields better water removal and product dryness, as observed in earlier works. However, the current intensity should be limited otherwise ohmic losses become prejudicial to the PED energy consumption.

5. Higher pressures improve PED kinetics and lead to higher water removal and cake dryness. For PED at 15 bar and $100 \mathrm{~mA}$, the bentonite reached $40 \% \mathrm{w} / \mathrm{w}$ solid for $0.7 \mathrm{kWh} / \mathrm{kg}$ of water removed.

6. The parameter $\varphi(\varepsilon)$ in equation (1) evolves during the process, leading to a reduction of the electroosmotic flow rate. In order to analyse PED precisely, it is important to make clear the dependence of $\varphi(\varepsilon)$ (thus of electroosmotic flow rate) on the porosity and pressure.

\section{NOMENCLATURE}

$D \quad$ dielectric constant $(\mathrm{F} / \mathrm{m})$

E electric field intensity $(\mathrm{V} / \mathrm{m})$

I current intensity (A)

$k$ particle shape factor

$P_{L} \quad$ liquid pressure in cake pores $(\mathrm{Pa})$

$q \quad$ superficial liquid velocity $(\mathrm{m} / \mathrm{s})$

$q_{E} \quad$ liquid velocity due to electroosmotic dewatering $(\mathrm{m} / \mathrm{s})$

$q_{P} \quad$ liquid velocity due to mechanical dewatering $(\mathrm{m} / \mathrm{s})$

$t \quad$ time (s)

$V \quad$ overall filtrate volume $\left(\mathrm{m}^{3}\right)$

$V_{E} \quad$ filtrate volume due to electroosmotic dewatering $\left(\mathrm{m}^{3}\right)$

$V_{P} \quad$ filtrate volume due to mechanical dewatering $\left(\mathrm{m}^{3}\right)$

Greek symbols

$\alpha \quad$ specific cake resistance $(\mathrm{m} / \mathrm{kg})$

$\Delta P \quad$ filtration pressure $(\mathrm{Pa})$

$\varepsilon \quad$ porosity

$\zeta \quad$ particle zeta potential $(\mathrm{V})$

$\mu \quad$ liquid viscosity ( $\mathrm{Pa} \mathrm{s}$ )

$\rho_{S} \quad$ density of solid particles $\left(\mathrm{kg} / \mathrm{m}^{3}\right)$

$\varphi(\varepsilon) \quad$ function of the cake porosity 


\section{ACKNOWLEDGEMENTS}

The authors would particularly like to thank Chris Manning for technical assistance.

\section{REFERENCES}

Akay G. and Wakeman R.J., 1997, Electric field enhanced crossflow microfiltration of hydrophobically modified water soluble polymers, J. Membrane Science, 131, 229-236.

Barton W.A., Miller S.A. and Veal C.J., 1999, The electrodewatering of sewage sludges, Drying Technology, 17, 497-522.

Ghirisan A., Weber K. and Stahl W., 2002, The influence of an electrical field on filtration and washing, Trans. Filtration Society, 2(3), 56-60.

Gopalakrishnan S., Mujumdar A.S. and Weber M.E., 1996, Optimal off-time in interrupted electroosmotic dewatering, Separations Technology, 6(3), 197-200.

Hofmann R. and Posten R., 2003, Improvement of dead-end filtration of biopolymers with pressure electrofiltration, Chemical Engineering Science, 58(17), 3847-3858.

Iwata M., Igami H. and Murase T., 1991, Analysis of electroosmotic dewatering, J. Chemical Engineering Japan, 24(1), 45-50.

Ju S., Weber M.E. and Mujumdar A.S., 1991, Electroosmotic dewatering of bentonite suspensions, Separations Technology, 1(4), 214-221.

Larue O. and Vorobiev E., 2004, Sedimentation and water electrolysis effects in electrofiltration of kaolin suspension, AIChEJ, 50, 3120-3133.

Larue O., Mouroko-Mitoulou T. and Vorobiev E., 2001, Filtration, cake washing and pressurised electroosmotic dewatering of a highly conductive silica suspension, Trans. Filtration Society, 1(2), 31-37.

Lockhart N.C., 1983a, Electroosmotic dewatering of clays, I. Influence of voltage, Colloids and Surfaces, 6, 229-238.

Lockhart N.C., 1983b, Electroosmotic dewatering of clays, II. Influence of salt, acid and flocculant, Colloids and Surfaces, 6, 239-251.

Lockhart N.C., 1983c, Electroosmotic dewatering of clays, III. Influence of clay type, exchangeable cations and electrode materials, Colloids and Surfaces, 6, 253-269.

Lockhart N.C., 1986, Electroosmotic dewatering of fine suspensions, in Recent Advances in Solid - Liquid Separation, Muralidhara H.S. (Ed.), pp.242, Battelle Press, Columbus.

Lockhart N.C. and Hart G.H., 1988, Interrupted electroosmotic dewatering of clay suspensions, the efficacy of current interruptions, Drying Technology, 6(3), 415-423.

MacInnes J.M., Du X., and Allen R.W.K., 2003, Prediction of electrokinetic and pressure flow in a microchannel T-junction, Physics of Fluids, 15(7), 1992-2005. 
Moulik S.P., 1971, Physical aspects of electrofiltration, Current Research, 5, 771-775.

Overbeek J.Th.G. and Bijsterbosch B.H., 1979, The electrical double layer and the theory of electrophoresis, Elsevier/North-Holland Biomedical Press, Amsterdam.

Shirato M., Aragaki T., Manabe A. and Takeuchi N., 1979, Electroforced sedimentation of thick clay suspensions in consolidation region, AlChEJ, 25(5), 855-863.

Sprute R.H. and Kelsh D.J., 1980, Dewatering fine particle suspensions with direct current, Proc. International Symposium on Fine Particle Processing Vol. 2, pp. 1828-1844, Las Vegas, Nevada.

Tarleton E.S. and Wakeman R.J., 1990, Microfiltration enhancement by electrical and ultrasonic force fields, Filtration \& Separation, 27(3), 192-194.

Tarleton E.S., Wakeman R.J. and Liang Y., 2003, Electrically enhanced washing of ionic species from fine particle filter cakes, Trans. IChemE, 81, 201-210.

Vijh A.K., 1999, Electroosmotic dewatering (EOD) of clays and suspensions: Components of voltage in an electroosmotic cell, Drying Technology, 17(3), 565-574.

Visvanathan C. and Ben Aïm R., 1989, Application of an electric field for the reduction of particle and colloidal membrane fouling in crossflow microfiltration, Separation Science and Technology, 24, 383.

Vorobiev E. and Jany S., 1999, Etapes de filtration frontale assistée par un champ électrique, Entropie, 219, 23-28.

Wakeman R.J., 1982, Effects of solids concentration and pH on electrofiltration, Filtration \& Separation, 19(7/8), 316-319.

Wakeman R.J., 1998, Electrically enhanced microfiltration of albumin suspensions, Trans IChemE, 76(C), 53-59.

Wakeman R.J. and Sabri M.N., 1995, Utilizing pulsed electric fields in crossflow microfiltration of titania suspensions, Trans IChemE, 73(A), 455-463.

Wakeman R.J. and Tarleton E.S., 1998, Filtration: equipment selection, modelling and process simulation, Elsevier, Oxford.

Wakeman R.J. and Tarleton E.S., 1991, An experimental study of electroacoustic crossflow microfiltration, Trans IChemE, 69(A), 386-397.

Weber K. and Stahl W., 2002a, Improvement of filtration kinetics by pressure electrofiltration, Separation Purification and Technology, 26(1), 69-80.

Weber K. and Stahl W., 2002b, Influence of an electric field on filtration in a filter press, Trans. Filtration Society, 2(4), 88-93.

Yoshida H., Shinkawa T. and Yukawa H., 1985, Water content and electric potential distributions in gelatinous bentonite sludge with electroosmotic dewatering, J. Chemical Engineering Japan, 18(4), 337-342.

Yoshida H., Kitajyo K. and Nakayama M., 1999, Electroosmotic dewatering under A.C. electric field with periodic reversals of electrode polarity, Drying Technology, 17, 539-554. 
Yu A.B., Zou R.P. and Standish N., 1996, Modifying the linear packing model for predicting the porosity of nonspherical particle mixtures, Industrial Engineering Chemistry Research, 35(10), 3730-3741.

Yukawa H., Chigira H., Hoshino T. and Iwata M., 1971, Fundamental study of electroosmotic filtration, J. Chemical Engineering Japan, 4, 370-376.

Yukawa H., Kobayashi K., Tsukui Y., Yamano S. and Iwata M., 1976, Analysis of batch electrokinetic filtration, J. Chemical Engineering Japan, 9, 396-401.

Zimmerman W.B. and Routh A.F., 2004, Distribution of particles during solvent evaporation from films, Chemical Engineering Science, 59(14), 2961-2968. 


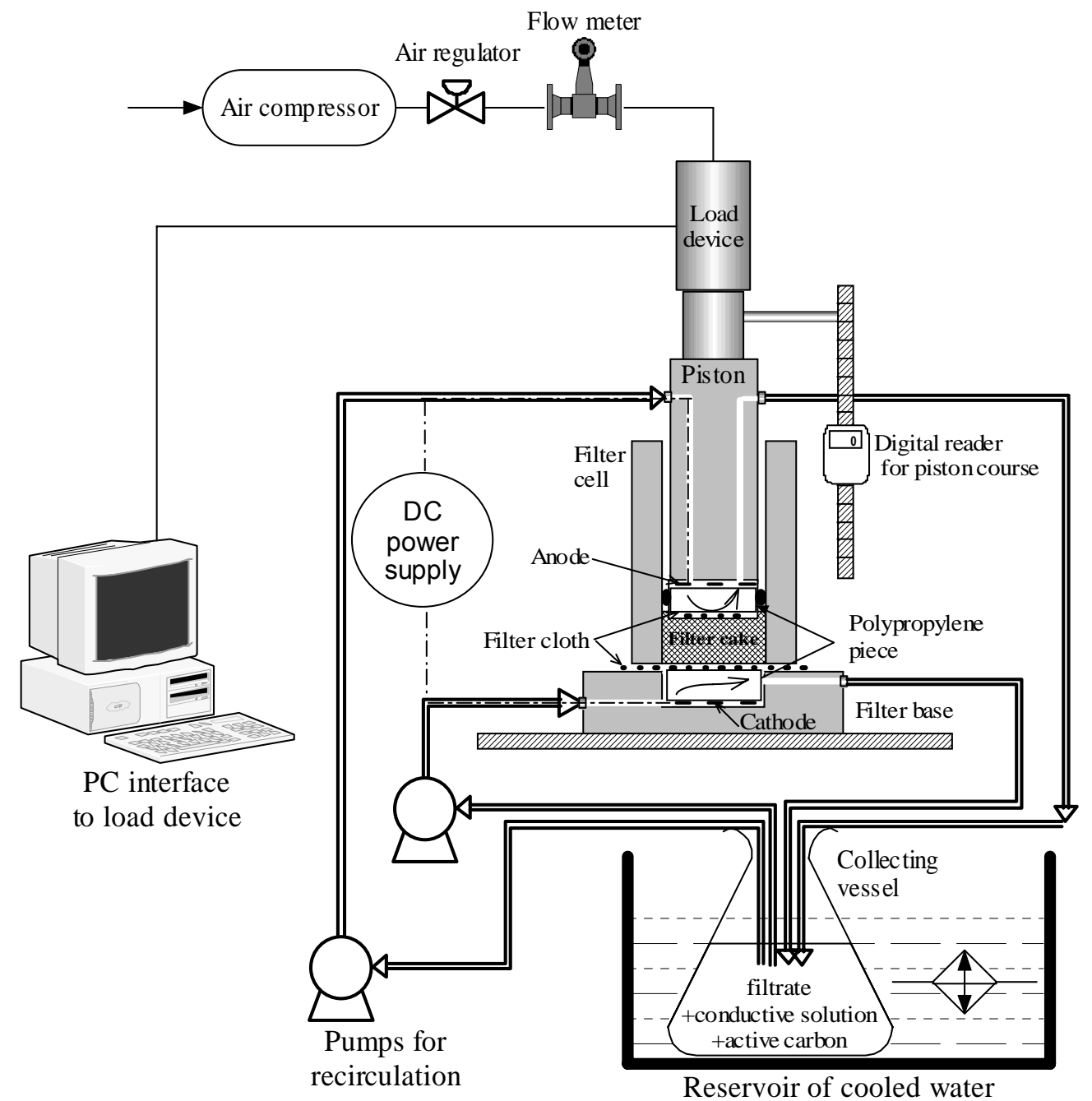

Figure 1: Experimental set-up comprising a filter cell and an arrangement to remove the electrolysis products and heat from the filter cell during PED. 


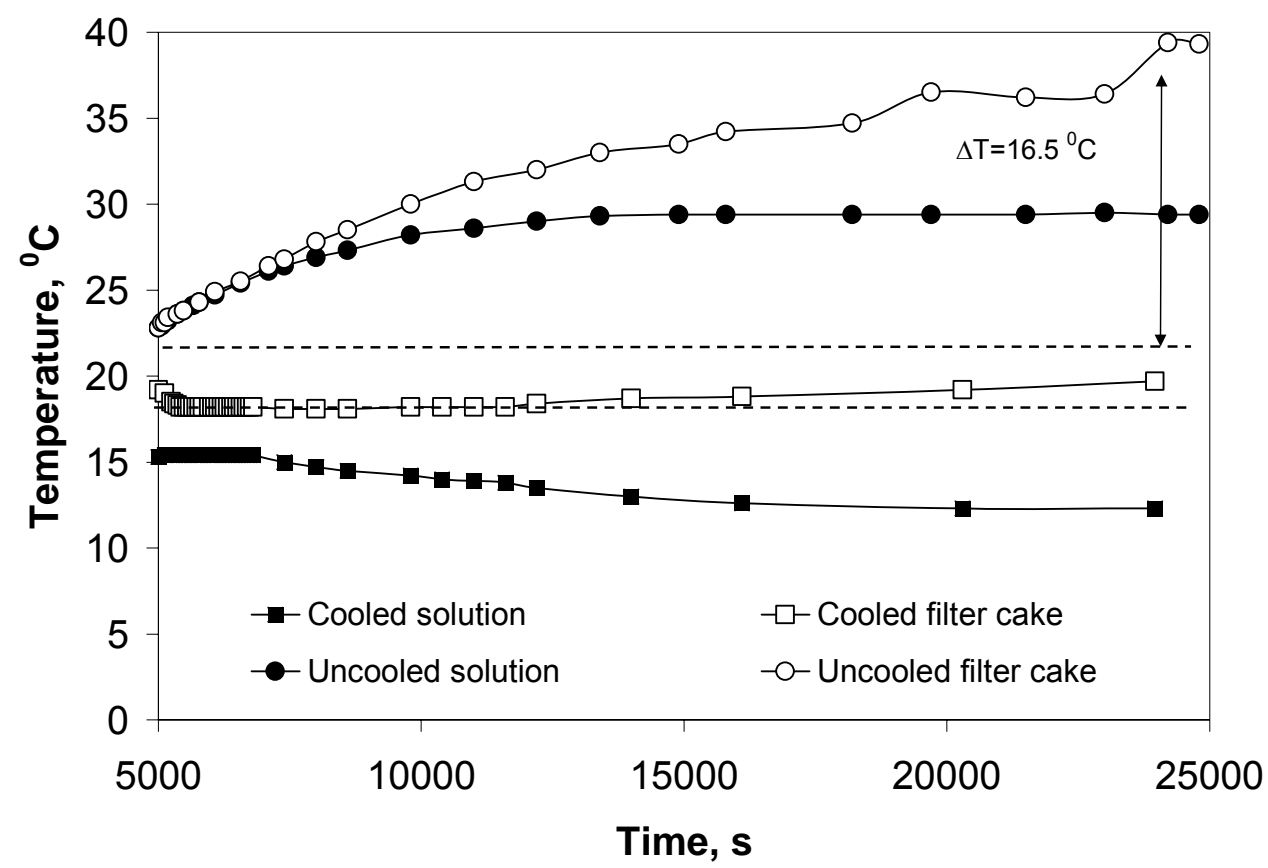

Figure 2: Temperatures in filter cake and in the conductive solution in PED (bentonite suspension: $8.5 \% \mathrm{w} / \mathrm{w}, \mathrm{pH} 9,6 \mathrm{mS} / \mathrm{cm}$; PED carried out after $5000 \mathrm{~s}$ of filtration).

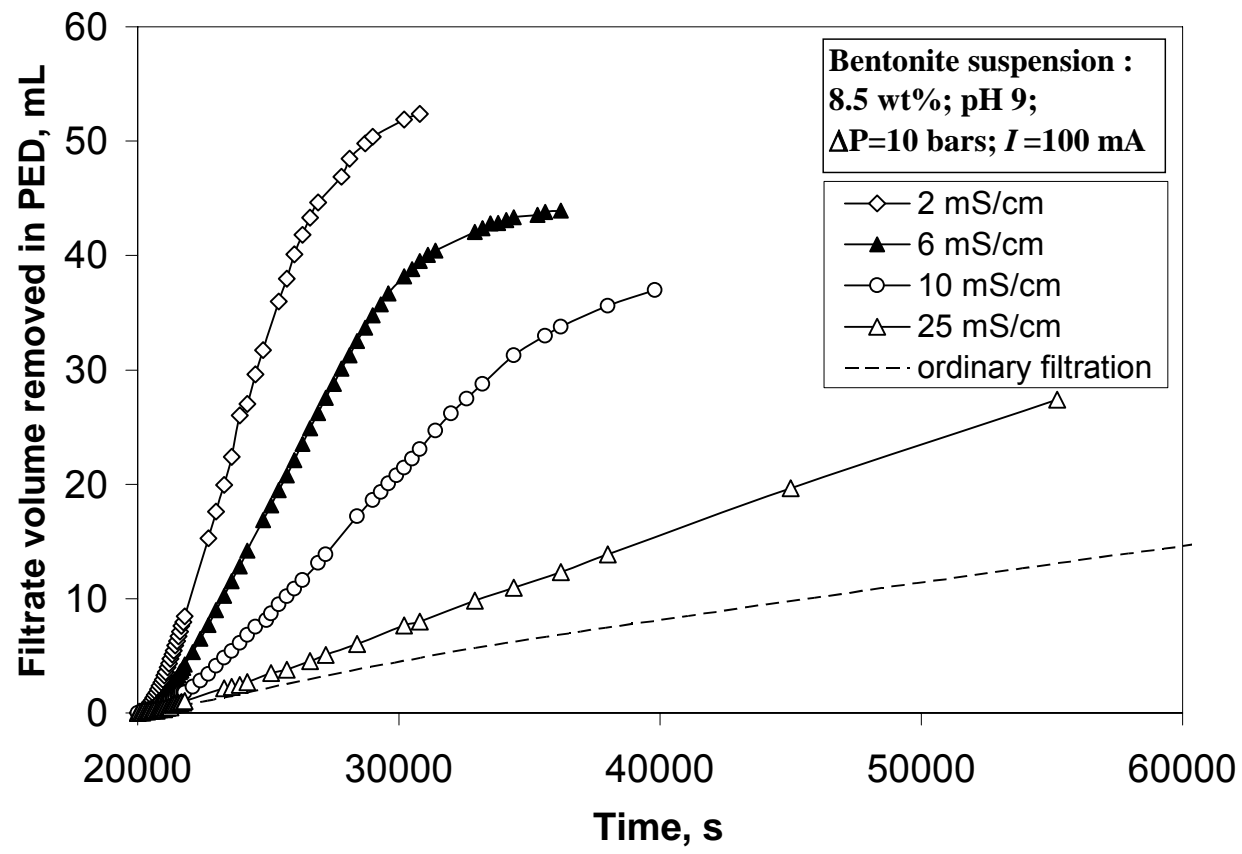

Figure 3: Filtrate volume removed by PED for different conductivities of bentonite suspension (PED carried out after $20,000 \mathrm{~s}$ of filtration). 


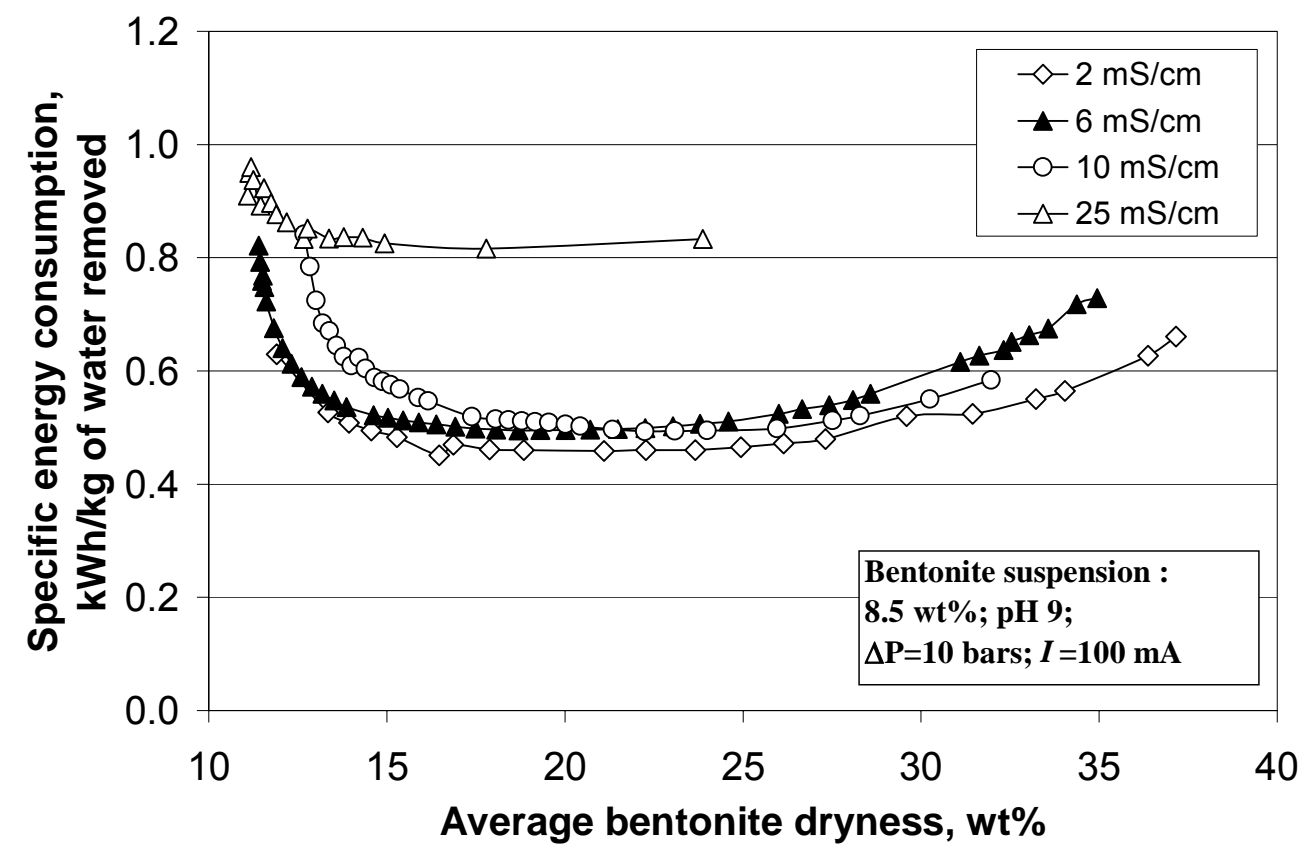

Figure 4: Specific energy consumption in the PED experiments displayed in Figure 3.

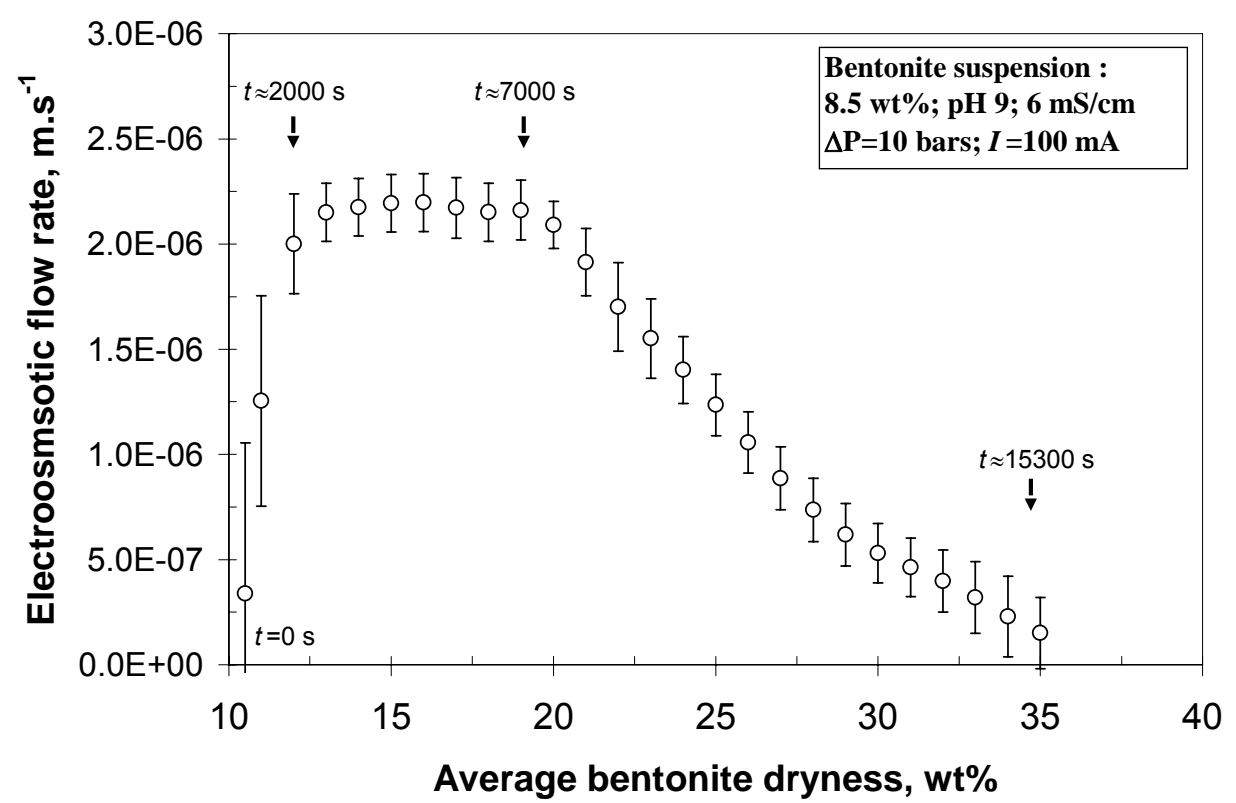

Figure 5: Evolution of the electroosmotic flow rate (expressed in $\mathrm{m} / \mathrm{s}$ ) in three reproduced PED experiments (PED carried out after 20,000 s of filtration). 


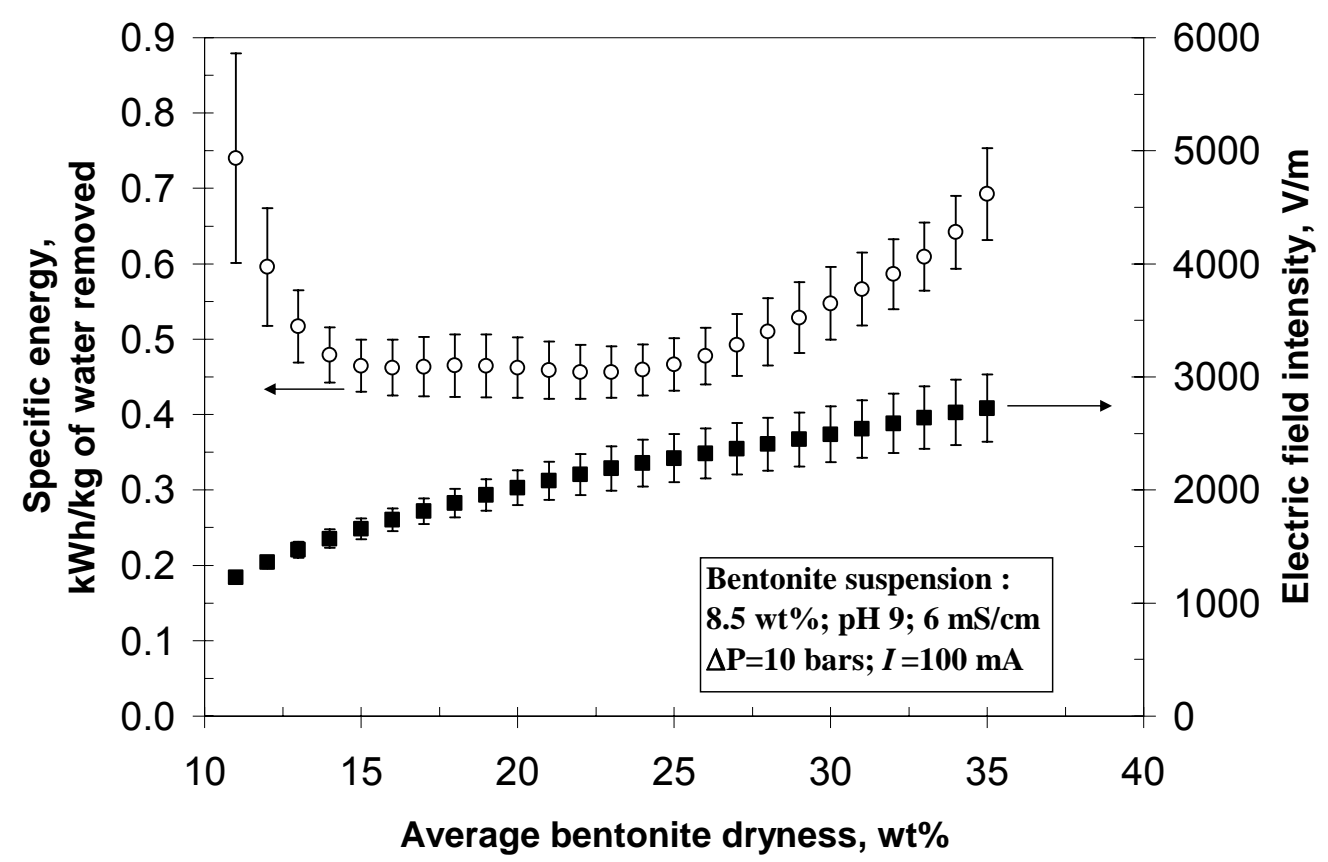

Figure 6. Specific energy consumption in the PED experiments displayed in Figure 5.

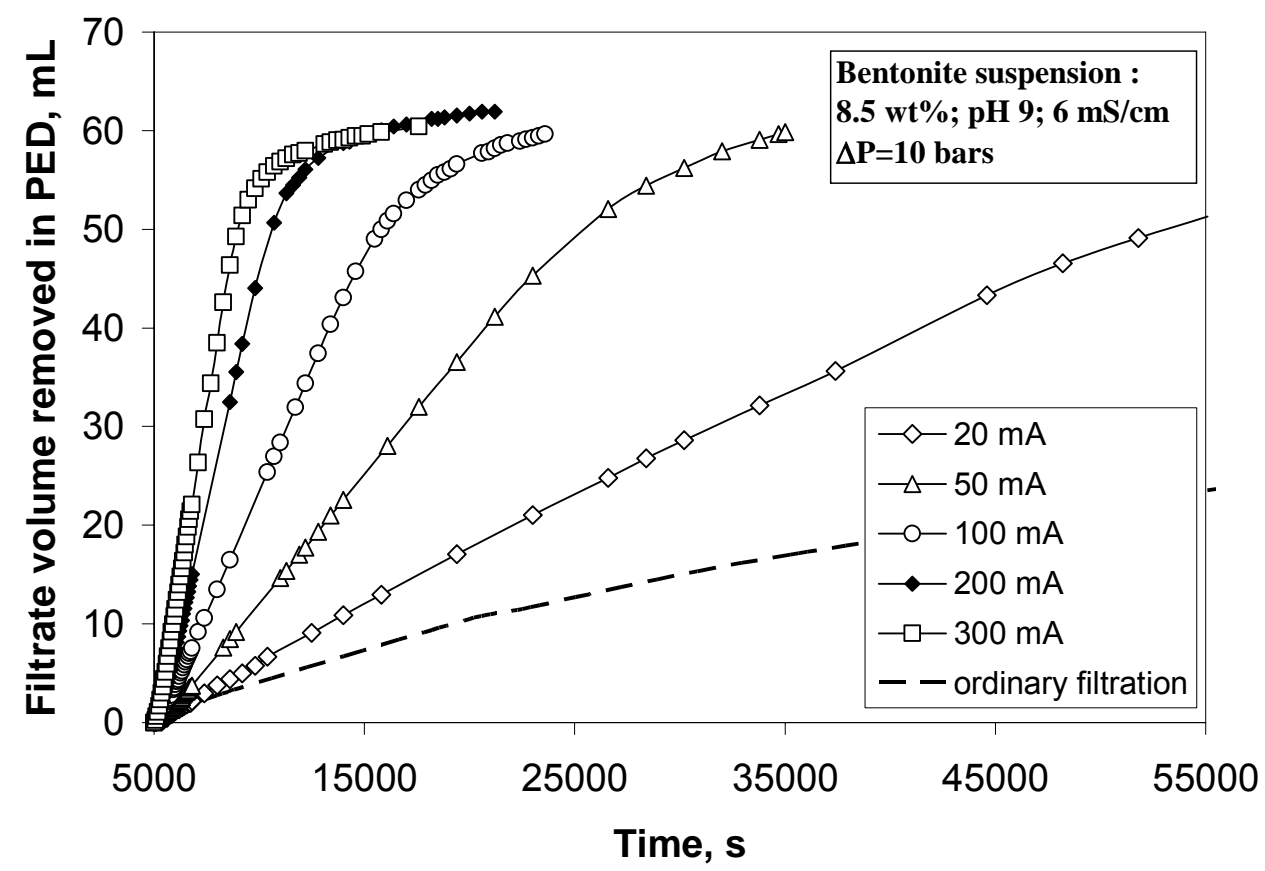

Figure 7: Filtrate volume removed by PED with different current intensities (PED carried out after $5000 \mathrm{~s}$ of filtration). 


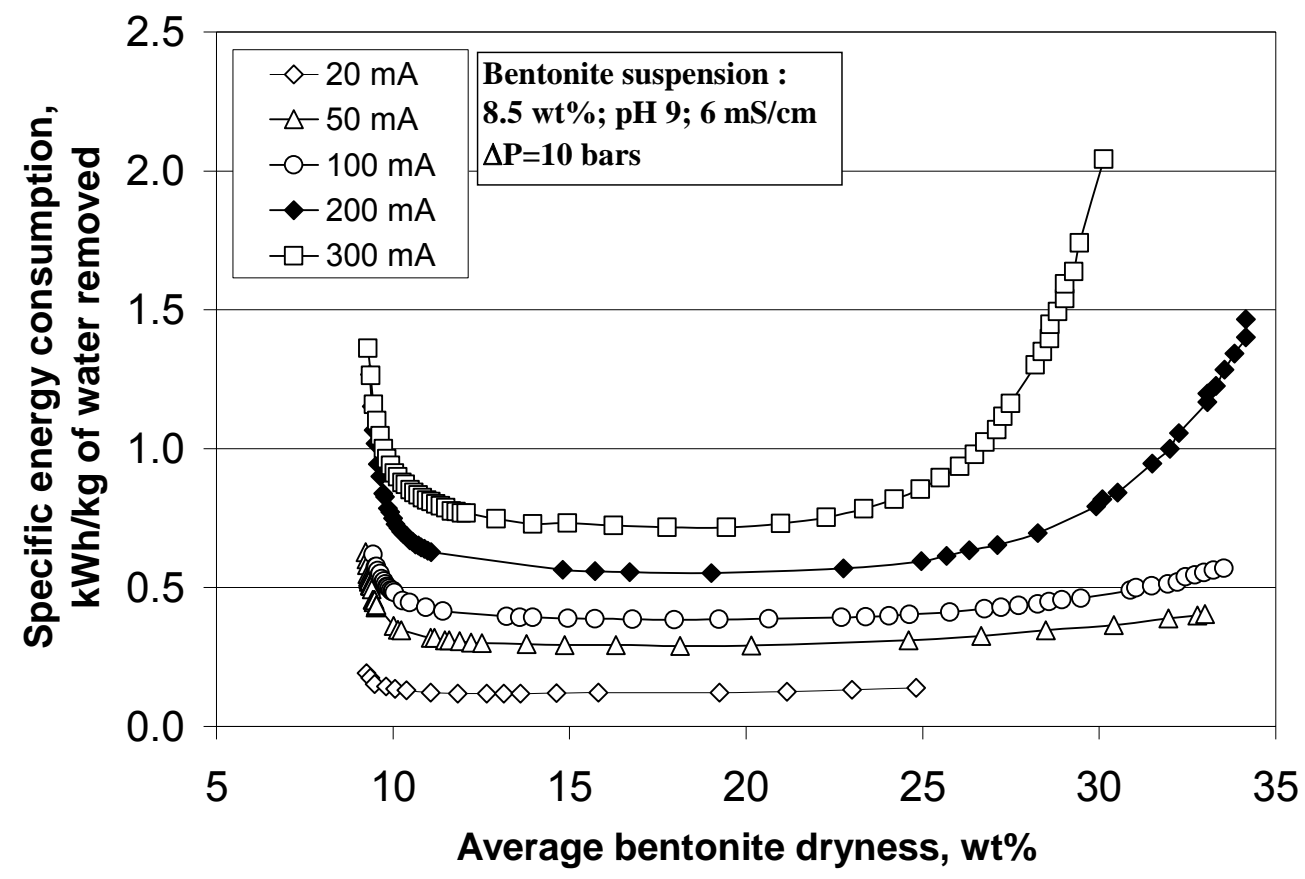

Figure 8: Specific energy consumption in the PED experiments displayed in Figure 7.

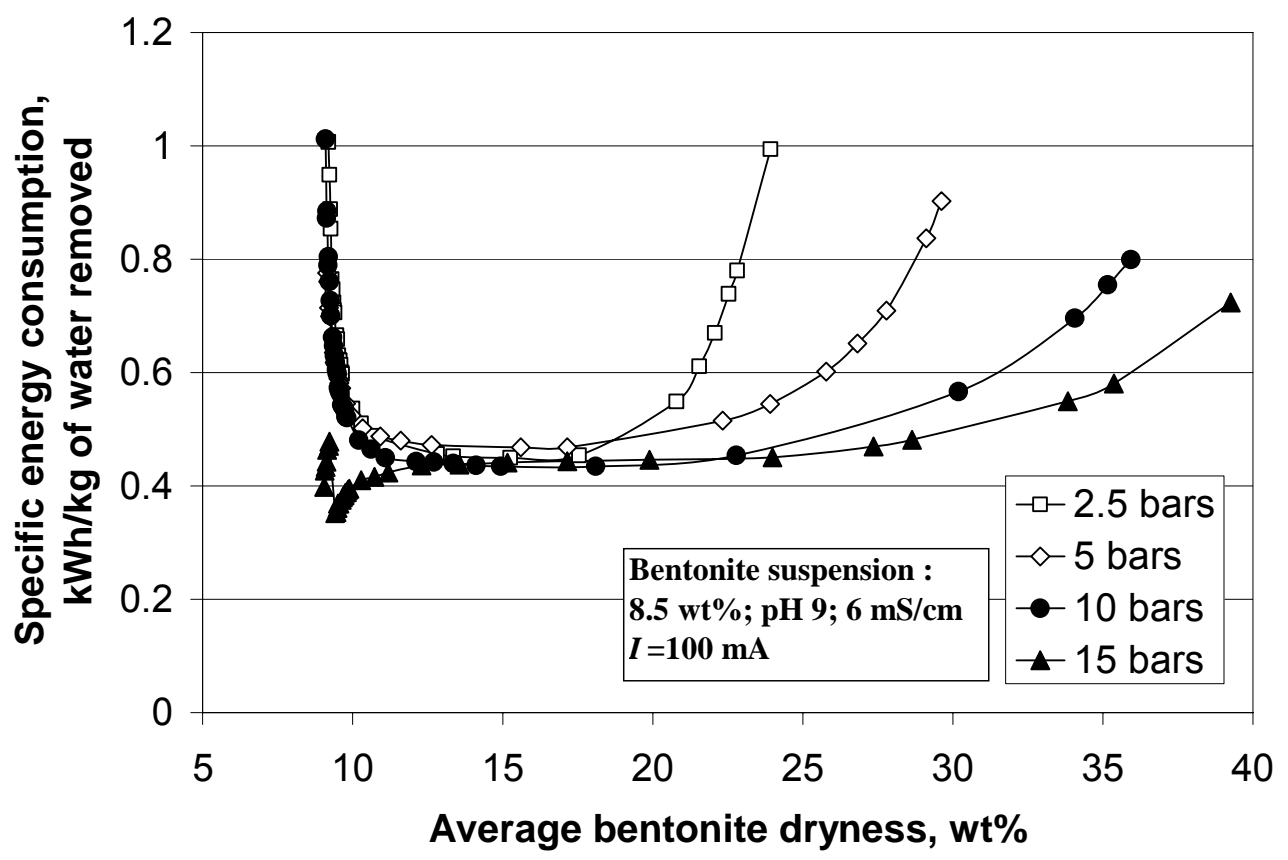

Figure 9: Specific energy consumption in PED with different pressures (PED carried out after 5000 $s$ of filtration). 


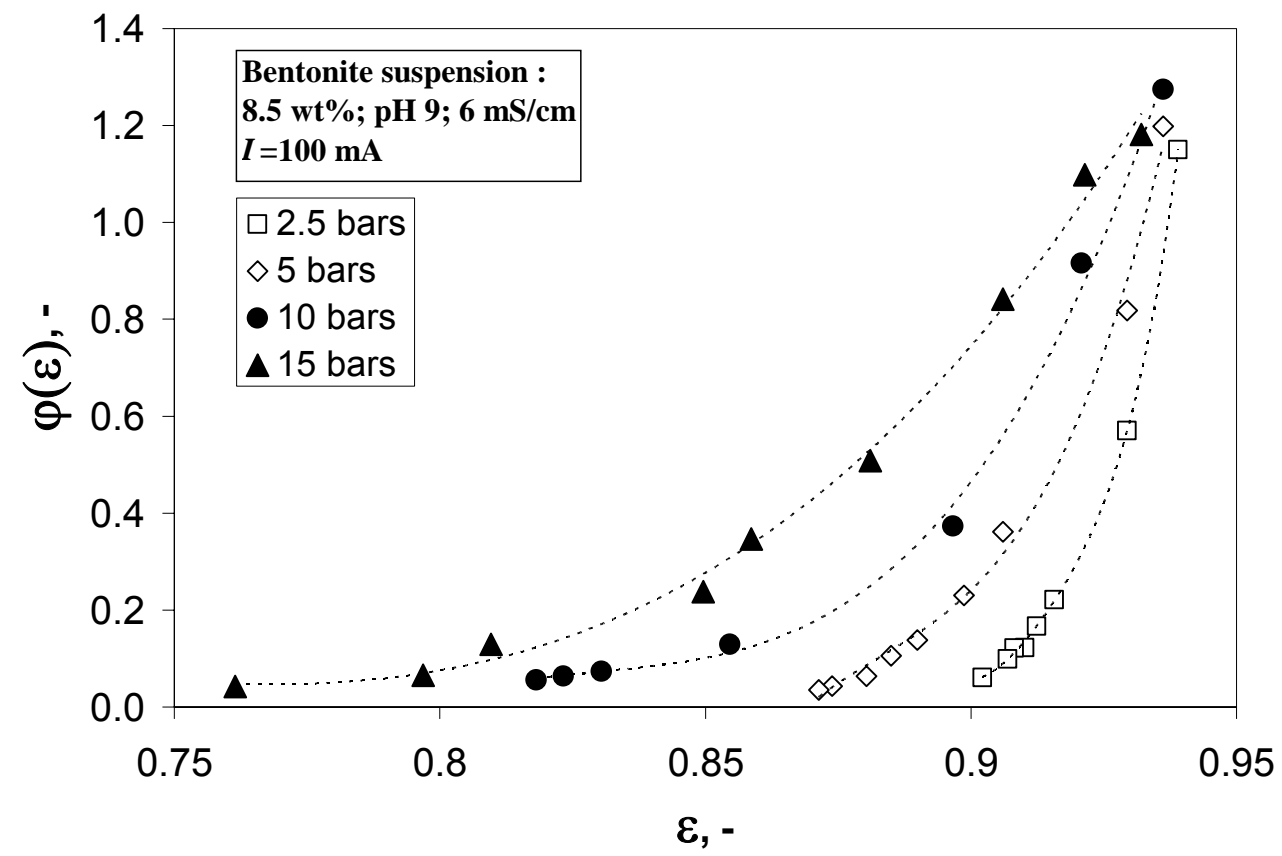

Figure 10: Evolution of the function of porosity $\varphi(\varepsilon)$ versus the bentonite porosity $\varepsilon$ in the PED experiments displayed in Figure 9.

\begin{tabular}{|c|c|c|c|}
\hline $\begin{array}{c}\text { Bentonite } \\
\text { conductivity }(\mathrm{mS} / \mathrm{cm})\end{array}$ & $E(\mathrm{~V} / \mathrm{m})$ & $q_{E}(\mathrm{~m} / \mathrm{s})$ & $\zeta(\mathrm{mV})$ \\
\hline 2 & 3200 & $3.33 \times 10^{-6}$ & -16.3 \\
6 & 2000 & $2.20 \times 10^{-6}$ & -17.2 \\
10 & 1200 & $1.15 \times 10^{-6}$ & -15.0 \\
25 & 700 & $3.50 \times 10^{-7}$ & -7.8 \\
\hline
\end{tabular}

Table 1: Particles zeta potential calculated from the electric field intensity, electroosmotic flow rate, cake porosity: 0.92 (taken at cake dryness $20 \% \mathrm{w} / \mathrm{w}$ ) for different bentonite conductivities. 